\title{
STIMULATION METHOD ON FAST RESPONSE AUDIOMETRY
}

\author{
KAZUOKI KODERA, M. D., OSAMU YAMADA, M. D., \\ ROBERT F. HINK, Ph. D., JUN-ICHI SUZUKI, M. D. \\ Department of Qtolaryngology Teikyo University School of Medicine, Tokyo \\ (Director: J. Suzuki, M. D.)
}

\begin{abstract}
Effects of stimulus rise-time, duration, number and interstimulus interval of $1000 \mathrm{~Hz}$ tone bursts on the auditory-evoked fast responses were studied in order to find appropriate stimulation methods for objective audiometry. Increase in rise-time of the tone bursts from 5 to 20 msec resulted in increased peak latencies for all of the components (BSR, Na, $\mathrm{Pa}$ ). The increase in rise-time also was associated with smaller peak-to- peak amplitudes (BSR-Na, $\mathrm{Na-Pa}$, $\mathrm{Pa}-\mathrm{Nb})$. On the other hand, increase in duration of the tone bursts with the same rise-time $(5 \mathrm{msec})$ affected neither the peak latencies nor the peak-to-peak amplitudes. These results indicated that there is little difference of frequency specificity among the various components of fast responses. The BSR-Na amplitude was not significantly influenced by increasing the number of stimuli from 500 to 4000 . The $\mathrm{Na}-\mathrm{Pa}$ and $\mathrm{Pa}-\mathrm{Nb}$ amplitudes decreased as the number of stimuli was increased to 1000 . The noise levels also decreased as the number of stimuli was increased, and this effect was greater than for either the $\mathrm{Na}-\mathrm{Pa}$ or $\mathrm{Pa}-\mathrm{Nb}$ amplitudes. Thus response identifiability was improved with increase of stimulus number. The BSR-Na amplitude did not decrease as the interstimulus interval was decreased from 104 to $32 \mathrm{msec}$. On the other hand, the $\mathrm{Na}-\mathrm{Pa}$ and $\mathrm{Pa}-\mathrm{Nb}$ amplitudes significantly decreased as the interstimulus interval was decreased. Therefore, to decrease test time, a better method is not to decrease the number of stimuli but to decrease interstimulus interval. In conclusion, our data indicated that among the fast auditory-evoked responses the BSR-Na measurement was very suitable for use as a clinical audiometric index.
\end{abstract}

A $82-0470-13522$

\section{聴性速反応による聴力検査の刺激法}

\author{
帝京大学医学部酉鼠咽喉科学教室（主任：鈴木聤一教授） \\ 小誌一甽, 山用 修, ロバートヒンク, 鈴木 淳一
}

はじめに

聴性速反心（脳幹反応：BSR と中間潜時反心： $\mathrm{Na}$,

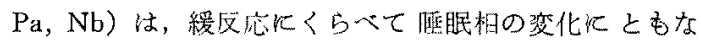
万反応波形や域値の变化が少ないことで，乘眼下の検查 を要する幼小児の他觉的㯖力検查として传れている。一 方聴性誘発反心の周波数選択性（純音聴力検查汶対応す 万周波数別の㯖力を測定する能力）については，潜時の

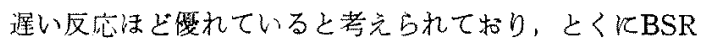

については低音域の聴力検査は因難と考兄られていた。 し加し，BSR Kよっても，500Hz，1000Hz，2000Hz D 各周波数の聴力方別個仁测定てきることが，最近明らか になった ${ }^{122)}$. 難㯖見の㯖力を周波数别化測定すること は, 補畾器の適合のたために必須であるので, 聴性速反 応の臨床上の有用性はさらに高方ってきた。

聴性速反応飞よる他觉的聼力検查では，周波数選択性 のよい反応を指標とすることと，一つの反応記録に要す 
る時間を短かくすることとが，臨床上必須である。本研 究で，これらの条件を満たす刺激法を求めることを目

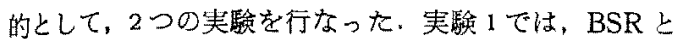
中間潜時反応のあいた洞波数選択性の差があるか否加

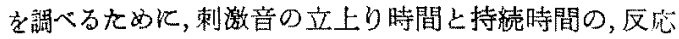
潜時とピーク間振幅への影響を検討した。実験 2 では， 聼性速反応記録江要する時間を短かくするための刺激法 を求めるために，反応のピーク間振愊にたいする，加算 平均回数之刺激間隔の影響孝検討した。

実 験 1 方 法

正常聼力者 8 例を対象とした. 反応の記録は、シール トした防音室内で読書中に行なった．電極は，脳波用且 電梗を使用し，頭頂部電極を陰極へ，検查側乳，突部電極 を陽極へ導き，非検查側乳突部電極を接地した。

生体加5の信号を增幅したのち(日本光電 RB-45030), データーレコーダー（TEAC R-410）飞記録した，これ
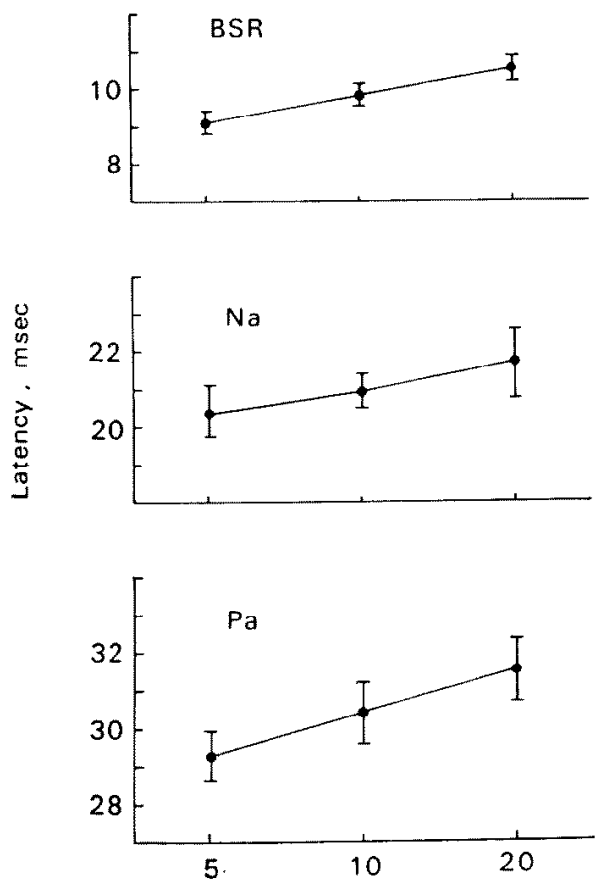

をのちに憗生しコンピューター（三栄测器 7T07）で加 算平均して誘発反虑記録した，記録系全体のフィルタ

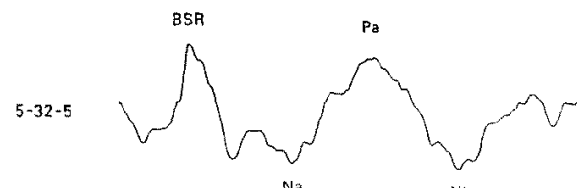

$20-2-20$

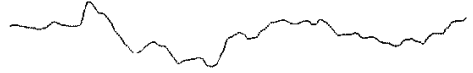

$-2-5$

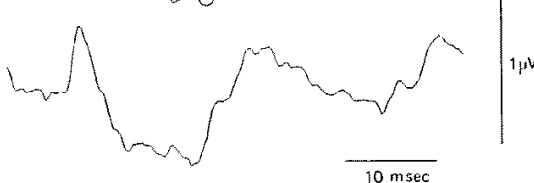

図 1 立上り時閒と持続時間の異なる刺激音に よる聼性速反応，反応の左几，刺激音の 立上り時閴一平坦部一立下り時間を示す 26藏男性
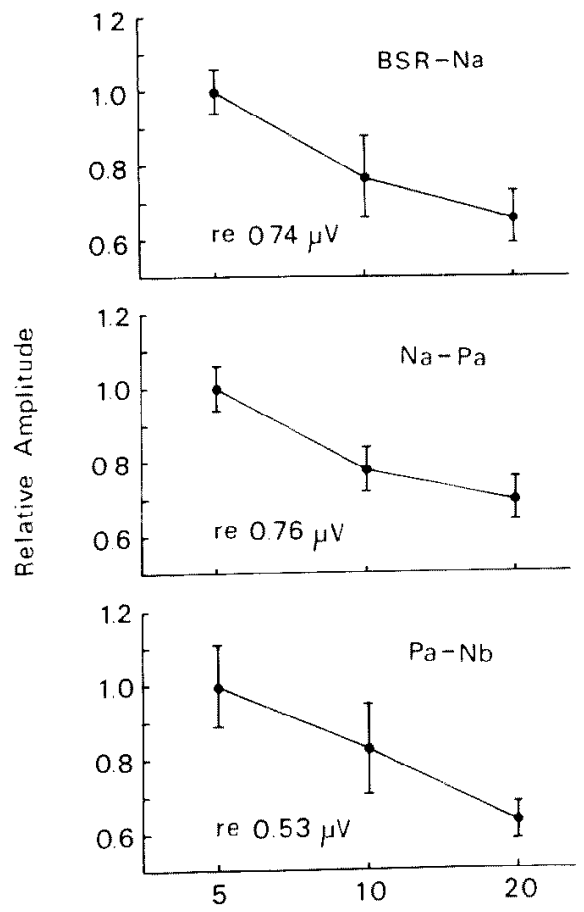

Rise Time, msec

図 2 立上り時間の变化による速反忘のピーク潜時（左）とピーク問振幅（右） の变化. 8 例の平均傎を示す（縦線は標準誤差を示す） 
一条件は, 24-1000 Hz の band pass である。

制激音は，ゼロスタートする $1000 \mathrm{~Hz}$ の tone burst で，1回每飞位相を逆転さ世，イトホーン（TDH 39） を通して与えた。刺溦音の立上り一平坦部一立下り時間 の組合せとして，5-32-5msec，10-22-10 msec，20-2-20 msec 特よび 5-2-5 $\mathrm{msec} の 4$ 種を用いた。この 4 種の 刺激音の平坦部の振幅は，同一とした。刺激望強度は， 5-32-5msec の tone burst にたいす名各被検者の自覚 域值を基準にして 60dBSL とした。この桑件ては 5-2-5 msec $の$ tone burst $の$ 旺强度山各被検者て $50 \pm 2 \mathrm{dBSL}$ であった. 刺激間隔 $500 \mathrm{msec} て 1000$ 回の加算平均を行 ない反心を記録し，ピーク間振幅を測定し比䡈した。

\section{実験 1 結果}

立上り時閻が $5 \mathrm{msec}, 10 \mathrm{msec}, 20 \mathrm{msec}$ の刺激觜によ る反灾のピーク潜時の平均值上標準誤差を図 2 の左に示 し、ピーク閻振幅の平均值と䅺準员差を图 20 右に示し

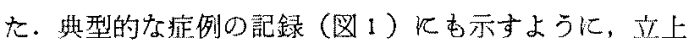
り時間を延辰すると， $\mathrm{BSR}, \mathrm{Na}, \mathrm{Pa}$ の各ピーク潜時は 延長し， BSR-Na，Na-Pa，Pa-Nb の各ピーク閶振幅は

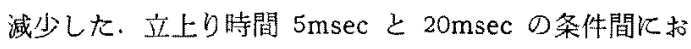
ける，それそれの潜時とそれぞれの振幅の差はすべて 統計的に有意であった（ $\mathrm{t}$ 检定， $\mathrm{p}<0.05)$. 立上り㭙間 の延長による潜時の延長と振幅の減少の程度は, 各ピー ク間流計的有意差はなかった（F検定）.

立上り時間が $5 \mathrm{msec} て ゙$ 同一であって，持続時間が異 なる2種の刺激音 (5-2-5 m 心の，ピーク潜時の平均馆上標準誤差を表 1 K示し，ピ 一ク閒振幅の平均做之標準誤差を表 2 飞示した。带型的 な症例の記録（四1）にも示すように，持続時間を延長

表 1 㳊激音の持続時間と反心潜時 (平均做と整準䏽差)

\begin{tabular}{cccc}
\hline 持続時間 & $\mathrm{BSR}$ & $\mathrm{Na}$ & $\mathrm{Pa}$ \\
\hline $12 \mathrm{msec}$ & $9.1 \pm 0.3$ & $20.8 \pm 0.7$ & $29.3 \pm 0.8$ \\
$42 \mathrm{msec}$ & $9.1 \pm 0.3$ & $20.4 \pm 0.7$ & $29.3 \pm 0.7$
\end{tabular}

変 2 刺激音の持続洔間とピータ間振幅 (平均倠上栖準䛊差)

\begin{tabular}{cccc}
\hline 持綕時閻 & $\mathrm{BSR}-\mathrm{Na}$ & $\mathrm{Na}-\mathrm{Pa}$ & $\mathrm{Pa}-\mathrm{Nb}$ \\
\hline $12 \mathrm{msec}$ & $0.79 \pm 0.07$ & $0.83 \pm 0.07$ & $0.53 \pm 0.06$ \\
$42 \mathrm{msec}$ & $0.74 \pm 0.06$ & $0.76 \pm 0.02$ & $0.53 \pm 0.06$ \\
\hline
\end{tabular}

しても，备ビーク潜時と各ピーク振幅は变化しなかっ た.

\section{実験 2 方法}

正常㯖力者 6 例を対象とし，睡纸下で能録を行なった 記䟿装置は，実験 1 と同一である，電極は，前頭部（毛

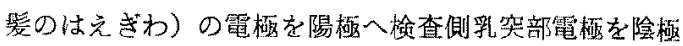
へ望き非梌查側乳突部電極を接地した。

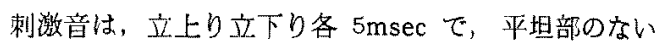
$1000 \mathrm{~Hz}$ の tone pip とした。刺激音强度は，刺激間嗝 $104 \mathrm{msec}$ K扣りる各被検者の自临域值を規準とし $50 \mathrm{~dB}$ SL とした. 刺激間隔は, $104 \mathrm{msec}, 73 \mathrm{msec}, 42 \mathrm{msec}$ 拉 よび $32 \mathrm{msec} の 4$ 種を用いた.4000回の刺激にたいする 生体からの信号をデーターレコーダ一に記録し, のちに 再生して誘発反心を記録した。

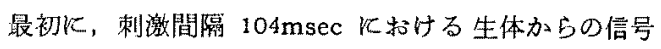
を再生し，500回，1000回，2000回，4000回の加算平均 による聼性速反応を記録し，各ピーク間振幅を測定し た.ついで，同一の生体からの信号を刺激音と同期させ 㘹で加算平均し，500回，1000回，2000回，4000回の 加算平均の記録で，任意の $30 \mathrm{msec}$ の間隹認められる最 大の電位差を求め, これを/イズレベルの指標とした。

最後に，104msec，73 $\mathrm{msec}, 42 \mathrm{msec}, 32 \mathrm{msec} の$ 刺激 間隔における，2000回刺激にたいする聴性速反応を2回 記録した．各被㛟者のピーク間振幅として，2つの記録 の平均傎を用いて，4種の刺激閒槅における各ピーク間 振幅を比較した。

\section{実験 2 結果}

1. 加算平均回数の聪性速反応への影唒

500回，1000回，2000回，4000回の加算平均に始ける， 各ピーク閏振幅とノイズレベルの平均值と標準䏽差を， 図 3 K示した，BSR-Na 振幅は，加算平均回数の影響を 受けなかった，Na-Pa 振幅は，1000回加算まで振幅が減 少した（ $\mathrm{t}$ 㭘定, $\mathrm{p}<0.01$ ). $\mathrm{Pa}-\mathrm{Nb}$ 振幅は, 2000回加算

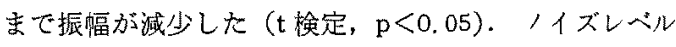
は，2000回加算まで減少した（t検定， $\mathrm{p}<0.01) .2000$ 回と4000回の間には，統計的有意差む認めなかった。加 算平均回数の增加に上もなう振幅隇少は，ノイズレベル が最大であったので，各反応の S/N 比は，扣算平均回 数が多いほと改善した，標準誤差に示される被検者間の バラツキは， Na-Pa で最大であり，BSR-Na で最小て あった。

2. 刺激間隔の㯖性速反心への影㗽

图 4 K，典型的定例の聼性速反応の記録を示す。刺激 

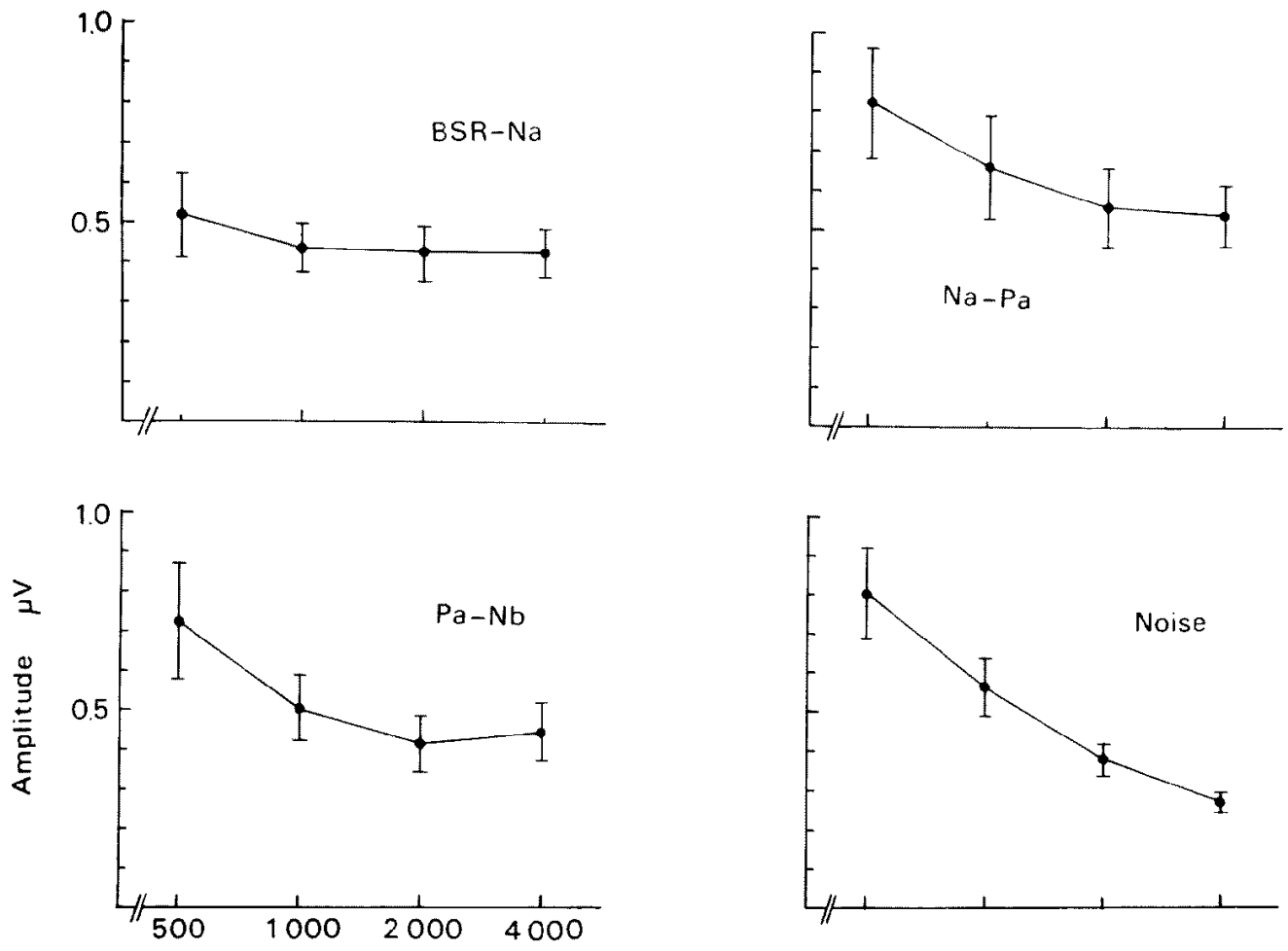

\section{Number}

园 3 加算平均回数の增加による速反応のピーク間振幅とノイズレベルの变化. 6 例の平均值と標準誤差を示す

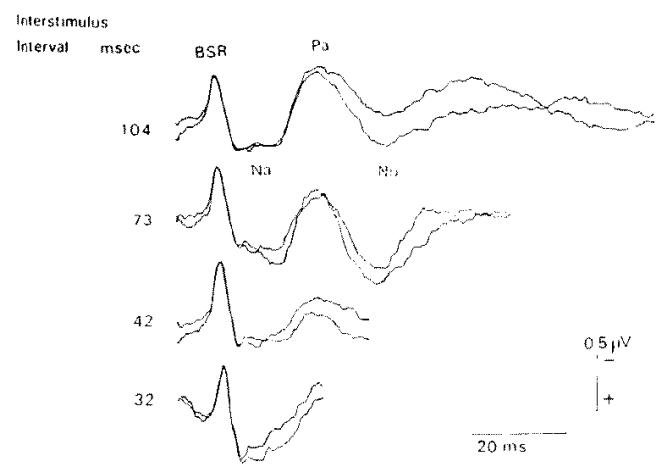

図 4 刺激間隔の異なる刺激法化上る聴性速反 忘. 反応の左汇刺激閪隔を示す 26 歳男 性

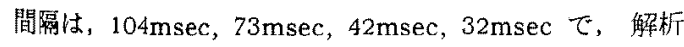
時間は，それそれ 102.4msec，71.7 $\mathrm{msec}, 41.0 \mathrm{msec}$ ， $30.7 \mathrm{msec}$ である。刺激間隔が反応潜時より短かくなる
ので, $42 \mathrm{msec} て ゙ は \mathrm{Nb} か ゙, 32 \mathrm{msec} て ゙ は \mathrm{~Pa} と \mathrm{Nb}$ 記録されない。

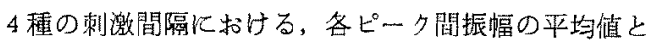
標準誤差を图5 亿示すＢSR-Na 振幅は，刺激間隔を短

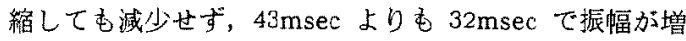
加した（ $\mathrm{t}$ 検定， $\mathrm{p}<0.01)$. Na-Pa振幅は，104msec 加 $542 \mathrm{msec}$ 亿短樎すると減少した（t 检定， $\mathrm{p}<0.05$ ). $\mathrm{Pa}-\mathrm{Nb}$ 振輻は，104msec 加 $573 \mathrm{msec}$ 飞短縮すると減 少した（検定， $\mathrm{p}<0.01$ ).

\section{考察}

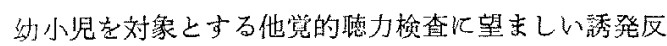
心の性留として，1. 周波数選択性が是いこと．2．短 時間で記録できること，3．反応の出現率に個体差が少 なく安定して䜘録できること，があげられる．今回の実 験結祭は，上述の 1，2の項目については，BSR-Na 成 分を指標にして，刺激間隔を短加くすることが良いこと 


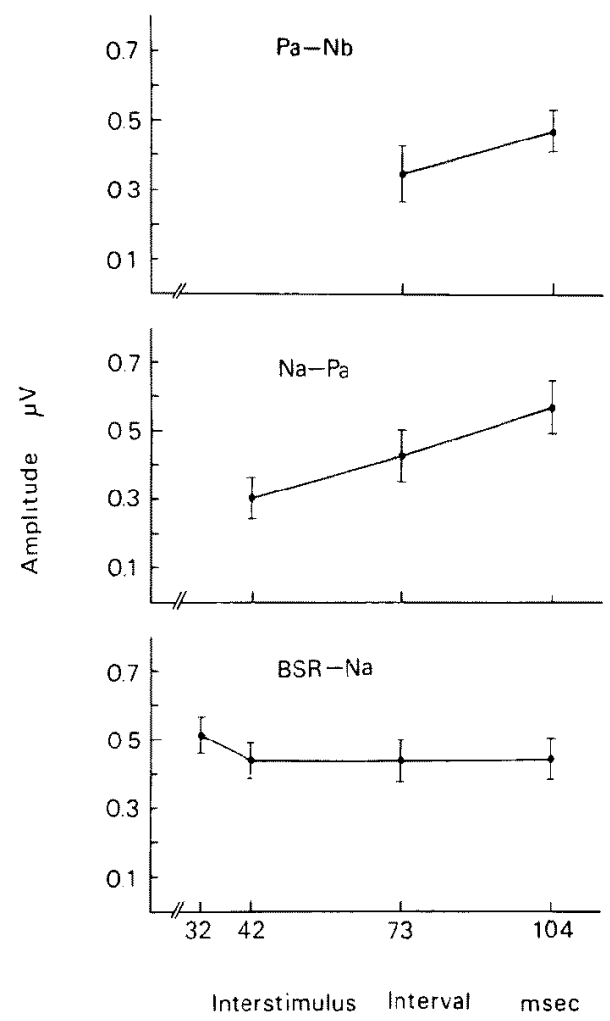

图 5 刺激間隔の変化による速反応の ピーク間振幅の変化. 6 例の平 均值と標準言至差圭示

を示した。

周波数選択性（純音聴力検查倸対応する，周波数別の 聴力を測定する能力）の直接的な检討法任，聴力検查が 可能な正常招よび難聴者を対象に誘発反応域値を求めて 純音域值上此校することである。嚄者方は，この方法に よって，BSR-Na を指標とする誘発反応が $500 \mathrm{~Hz}, 1000$ $\mathrm{Hz}, 2000 \mathrm{~Hz}$ Kおいて，臨床上十分飞良好な周波数選択 を備劣ていることを報告しだ、一方，聴性緩反応の周 波数選択性については, 音用始から $30 \mathrm{msec}$ 以内の刺激 音は，その平坦部香反応誘発に有効であることから，よ り上い周波数選択性があると考光られている゙3.

中間潜時反忘は，BSR 上楥反応の中間化位䈯するこ 之から，BSR にくらべて上り良い周波数選択性を備元 ているとの仮説があった，しかし，実娩 1 の結果では， 刺激音の立上り時問を延長した場台に BSR と中間潜時 反応に起る变化杜同様であった。また，刺激音の平坦部
を延長しても，BSR と中間潜時反応はとあに变化しな かった。これらの結果は，BSR-Na と，旮れ以降の Na$\mathrm{Pa}, \mathrm{Pa}-\mathrm{Nb}$ の間炕 周波数選快性の差がないととを示す ものである。

反応記録に要する時間を短縮するには，1，加算平均 回数を娍少させること，2．刺激間隔を短かくすること， の2つの方法吕考光られる，加算回数を減少させるこ上 は，図3の結果淿すように，S/N比を悪くするので反 応判定の信頼性を損なることとなり適切ではない，とく に, tone pip を刺激音として周波数別の㯖力安測定する 場合には，自覚域值飞近い音強度に括ける反応の記録加 必須である。その理由は，刺激音強度が弱いほど螖牛基 底板の刺激される頖囲峙狭くなり，得られた反応の周波

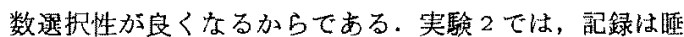
眠下で行なっているので生体からの/1ズは少ない条件 であるが，北景脳波などとよるノイズレベルの隇少は， 2000 回の加算平均まで有意汇減少した。したがって，上 くに反怘域值付近では，2000回位の加算平均㤎必要であ 落。

刺激間隔を短かくすることは，検查時間短縮のために 有効であった．実娩 2 の結果では，BSR-Na 振幅性刺激 間隔を $32 \mathrm{msec}$ Kしても振幅は減少しなかった。クリ， クを刺激音とする場合には，BSR とそれ机つづく頭頂 部除性の電位との間の振幅は，刺激間隔を短汃くしても 变化が少ない4257，今回の実験は，周波数選択性のある tone pip 飞上る速反岕化招いてす，BSR-Na 成分は同 様の性質を持つことを示した。刺激間隔を短かくする と，潜時の遲い反応が潜時の早い反応と重複して記録さ れる可能性がある. 図4 江示した刺激間隔 $32 \mathrm{msec}$ の方 が 42msec Kくらべて BSR-Na 振幅が増加する現象は， 刺激間隔 $32 \mathrm{msec}$ の条件では $\mathrm{Na}$ と Nb が電複して記 録されることによると推論できる。しかし，このような 重複は潜時の選い反空の振幅が刺激間隔の短縮儿と屯な い減少するのて，反応判定の障害にはならない。

反応の出現率中安定性行ついては，堀内 $5^{6)}$ 中沖津 $5^{7)}$ によって報告されている。煺眠幼児では，BSR 上 Naの 出現性は良好であるが，Pa の出現性は低下する。した がって，この点からも BSR-Na 在指標とすることが良 いと考兑られる。

\section{結論}

1. 聴性速反灾の各成分の閤には（BSR, $\mathrm{Na}, \mathrm{Pa}$ ), 周波 数選択性の差はない。 
2. 㯖性速反応を用いた周波数選択性のある他觉的慗力 検査では，検査時間短縮のために, BSR-Na 成分を指絮 として，刺激間隔を短かく $(32-40 \mathrm{msec})$ することが䟖 床上有用である。

\section{参真 献}

1) Kodera K, Yamane H, Yamada $O$ and Suzuki $J$-I: Brain stem response audiometry at speech frequencies. Audiology 16: 469-479 (1977)

2) Suzuki T, Hirai $Y$ and Horiuchi K: Auditory brain stem responses to pure tone stimuli. Scand. Audiol. 6: 51-55 (1977)

3) Onishi $S$ and Davis $H$ : Effects of duration and rise time of tone bursts on evoked V potentials. J. Acoust. Soc. Amer. 44: 582-591 (1968)

4) Goldstein R, Rodman $L B$ and Karlovich $R S$ :
Effects of stimulus rate and number on the early components of the averaged electroencephalic response. I Speech and Hearing Res. 15: 559566 (1972)

5) Terkildsen $K$, Osterhammel $P$ and Veld H: Farfield electrocochleography. Adaptation. Scand. Audiol. 4: 215-220 (1975)

6)煀内喍子：聴性䛵発反応の middle latency response の梌討，日耳舆 79：1549-1558（1976）

7) 洲泮卓二, 小林俊光, 河本和友, 広瀬富美于: 頭頂 部中間反庶 (Middld Latency Response) Kついて Audiology Jap. 20: 171-179 (1977)

(原稿受付 昭和53，12.6日)

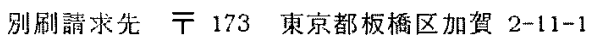

帝京大学医学部耳舆胭喉科学教室 小寺一興 